Open Access

\title{
Response to the global financial crisis: a follow-up study
}

\author{
Eric Hansen ${ }^{1 *}$ (D) and Erlend Nybakk ${ }^{2,3}$
}

\author{
* Correspondence: Eric.Hansen@ \\ oregonstate.edu \\ ${ }^{1}$ Department of Wood Science and \\ Engineering, College of Forestry, \\ Oregon State University, 119 \\ Richardson Hall, Corvallis, OR 97331, \\ USA \\ Full list of author information is \\ available at the end of the article
}

\begin{abstract}
Firm response to decline has seen renewed interest based on the impacts of the global financial crisis. Here, we investigate the long-lasting effects of decline on the innovativeness of firms and, ultimately, the performance outcomes of those actions. The study focuses on SMEs in the US forest products manufacturing sector. We analyze the situation within 89 firms with respect to innovativeness in the years 2008, 2012, and 2015. Theory suggests that firms increasing innovativeness in response to the crisis would subsequently decrease innovativeness as US markets improved. With respect to product innovativeness, we find convincing evidence that firms increasing innovativeness subsequently decreased innovativeness. With respect to process and business systems innovativeness, the evidence is weaker, but indicative of a decrease in innovativeness between 2012 and 2015. Expected reduction in innovation efforts and increased focus on producing commodity products is not evident from our responding firms. Based on these findings, it is recommended that firms carefully consider their innovation investments/activities across the business cycle as a more consistent approach may be more productive.
\end{abstract}

Keywords: Organizational decline, Innovativeness, Firm performance

\section{Background}

Firm response to decline has seen renewed interest based on the impacts of the global financial crisis (GFC) (Sun et al. 2018; Zouaghi et al. 2018; Archibugi 2017; Ferreira and Teixeira 2016; Paunov 2012; Bancel and Mittoo 2011; Filippetti and Archibugi 2011). The interest derives from compelling evidence that innovation causes a host of positive outcomes for both individual firms and, collectively, entire economies (Petrakis et al. 2015; Hausman and Johnston 2014; Price et al. 2013; Madrid-Guijarro et al. 2013; Cefis and Marsili 2005). Despite the interest, there are few examples documenting the post-recession actions of firms (e.g., Brancati et al. 2017), especially those that attempted to innovate their way out of the recession. Once overall economic recovery from a recession begins, what do companies that increased their innovativeness tend to do? Do they maintain their increased innovativeness, or do they return to their previous norms? In addition, do those companies that increase innovativeness during a recession facilitate improved performance as markets recover? The GFC provides a unique opportunity to investigate firm actions in what Laperche et al. (2011) describe as a "laboratory of ideas."

Improved performance via increased innovativeness is assumed to be aspirational for managers but it is not clear how regularly it occurs (McKinley et al. 2014). This is an important question since innovation or organizational innovativeness is often accepted

(C) The Author(s). 2018 Open Access This article is distributed under the terms of the Creative Commons Attribution 4.0 International License (http://creativecommons.org/licenses/by/4.0/), which permits unrestricted use, distribution, and reproduction in any medium, provided you give appropriate credit to the original author(s) and the source, provide a link to the Creative Commons license, and indicate if changes were made. 
as positively impacting firm performance (Price et al. 2013; Tsai and Yang 2013; Rubera and Kirca 2012), despite contrary findings (Forsman and Temel 2011). In some cases, the type of innovation is an important element of the innovativeness-performance relationship. For example, process and business systems innovativeness may positively impact firm performance while product innovativeness may not (Hansen 2014), and this may be industry sector specific.

The US forest industry represents, perhaps, one of the most impacted manufacturing sectors during the GFC as its primary market, housing, fell by nearly $80 \%$ between 2006 and 2009 (Ince and Nepal 2012). The intensity of decline in its primary market is unprecedented in history and provides a unique situation to study the innovativeness-oriented actions of firms. In the present study, we build on Hansen (2014), use the GFC as a period of decline, and follow forest industry firms in the post-GFC period, specifically their situation in 2015 compared to 2012.

Little work has been done to follow the paths of companies as they adapt to what is now referred to as the new normal (Panwar et al. 2012). Here, we investigate the long-lasting effects of decline on the innovativeness of firms and, ultimately, the performance outcomes of those actions. Using data collected from the same firms over two time periods provides us with unique insights into the development of innovativeness across the GFC and ensuing recovery years. Accordingly, our overriding objective is to determine if increasing innovativeness is sustainable for firms across the GFC and subsequent recovery years.

McKinley et al. (2014) emphasize the issue of "What Happens?" with respect to decline scenarios. In the present study, we follow firms after their initial reactions to the GFC, when markets are recovering and the worst impacts of the recession have passed. In other words, we investigate the longevity of the attempts by firms to become more innovative and attempt to identify the outcomes of that increased innovativeness on performance. First, did the effort to become more innovative pay off in terms of increased performance, and second, once a company consciously chooses to become more innovative, is it a lasting component of company culture. On the other hand, does the return of a positive market situation mean that firms retreat from their proactive innovation stance toward the lower levels of innovativeness characteristic of pre-decline times?

Our longitudinal view across the time span of the GFC enables the key contribution of this work. We know that firms tend to respond to recession by either increasing or decreasing innovation efforts (McKinley et al. 2014), and the previous stage of this research showed that process and business systems innovativeness positively impact firm performance. The literature is sparse with respect to what happens next with firms. Accordingly, the primary contributions of this work are providing insights into the consequences of increasing innovativeness as a response to recession and identifying whether firms maintain higher levels of innovativeness once markets begin recovering from a recessionary period. We find that the increase in innovativeness is largely short term and economic recovery leads to firms decreasing innovativeness.

Innovativeness is a characteristic of an organization that has the propensity to create and/or adopt a new idea, object, or practice (Gebert et al. 2003; Rogers 2003; Nybakk 2012). In research focused on the forest sector, innovativeness is typically discussed following three categories: product, process, and business systems (Hovgaard and Hansen 2004). 
A self-report scale has been developed specific to forest industry manufacturers that assess the propensity to create and/or adopt products, manufacturing processes, and business systems (Knowles et al. 2008). Business systems innovativeness refers to the way that a company manages its business, and covers a range of possibilities from organizational structure to marketing routines. An innovation is something newly created or adopted by a firm. For example, innovation is "...any novel product, service or production process that departs significantly from prior product, service, or production process architectures" (McKinley et al. 2014, p 91). The importance of maintaining the conceptual difference between innovativeness and innovation has been emphasized in the literature (Garcia and Calantone (2002) and is especially relevant in the context of this work.

Much of the extant innovativeness work, both academic and governmental, focuses on firms conducting $R \& D$ and therefore equates innovative activities with high levels of risk (Madrid-Guijarro et al. 2013). However, innovativeness, as an element of firm culture, goes well beyond structured R\&D. For example, roughly half of innovating European firms are defined as non-R\&D innovators (Pro Inno Europe 2008). Such firms, for example, invest in acquiring new knowledge or new equipment (adoption) rather than creation of new products via an R\&D function. Non-R\&D innovators tend to persist with their innovativeness even in times of crisis (Sempre-Ripoll and Hervás-Oliver 2014). What this means in practice is that non-R\&D innovators can make less risky investments or conduct innovative activities that require little capital outlay. In addition, in times of recession when demand is low, firms may have slack resources in the form of employee time and can therefore pursue some types of innovative efforts at little additional cost. Being a non-R\&D innovator is strikingly different than an $R \& D$ innovator.

Research on organizational reaction to crisis has a long history, yet firm response to crisis remains poorly understood (Sarkar and Osiyevskyy 2018). Specifically, the decline literature has seen increased attention because of the GFC (e.g., McKinley et al. 2014). Latham and Braun (2009) use threat rigidity theory and prospect theory to provide an eloquent explanation of the potential responses by a firm. When faced with a decline situation, firms may choose to reduce costs and risks in an effort to ride out the storm (threat-rigidity), or they may proceed more proactively by taking risks, attempting to innovate, and trying to meet the decline head on with a strategic response (threat-innovation) (McKinley et al. 2014; Staw et al. 1981). It is also suggested that innovation does not slow during crisis, but accumulates and comes to life as the economy slowly recovers (Florida 2010). Existing work suggests that firms innovating in response to recession have distinct differences from those choosing to stay steady or retreat from their investment. For example, Archibugi et al. (2013a) describe firms increasing investments as "swimming against the stream" and find these firms to be smaller, more collaborative, more likely to seek new markets, and less likely to compete on costs. Their work focuses on innovation expenditure and finds only $9 \%$ of European companies increased innovation investment during the GFC. In the context of the construction industry and the GFC, Tansey et al. (2014) found a combination of cost-cutting measures and business systems innovations, illustrating both the threat-rigidity and threat-innovation approaches. However, in their study, these approaches were taken simultaneously by each of the case companies studied. 
Other work focuses more narrowly on a distinct company function such as marketing and finds that while the majority of firms reduced marketing budgets in response to the GFC, others chose to invest (Rollins et al. 2014). Smaller startup software firms are more likely to make marketing investments than larger established firms (Latham 2009), and some forest sector firms clearly focused on market development as a response to the GFC (Han and Hansen 2016). Finally, firms proactively investing in marketing activities can benefit both during and after a recession (Srinivasan et al. 2005).

As with general innovativeness research, most decline/innovation work focuses on $R \& D$ (e.g., Llach et al. 2012; Archibugi et al. 2013b; Amore 2015), sometimes referred to as innovation investment (Latham and Braun 2009), as a proxy for innovativeness. Also, much of the GFC-focused decline research relies on large-scale governmental databases (e.g., Llach et al. 2012; Brzozowski and Cucculelli 2016; Holl and Rama 2016). Accordingly, the bulk of existing work differs significantly from that in the present study where we use self-report innovativeness and a survey of firms in a specific industry sector.

Specific to the US forest sector, firms have a reputation of using export markets to eliminate excess production (Rich 1981) during a recession, rather than strategically entering export markets. It is said that they bounce in and out of export markets based on need and the overall health of domestic markets. The GFC clearly pushed some forest sector firms to enter export markets (Han and Hansen 2016, Sasatani and Eastin 2016). This is one action taken by forest sector firms that can be easily seen in trade data (USDA 2018). In addition, earlier work (Hansen 2014) shows a strong proportion of forest sector firms increasing innovativeness as a reaction to the GFC. What remains unexplored is whether this increase holds as the GFC receded and markets began to return to normal. Given the historical pattern mentioned above, it can be expected that firms would again return to the familiar realm of domestic markets as they recovered, post-GFC. Overall, given the discussion above, we pose three related hypotheses, each connected to different evidence regarding firm innovativeness.

H1a: Firms that increased innovativeness during the GFC decreased innovativeness post-GFC.

H1b: Firms that increased innovativeness during the GFC decreased their level of innovation efforts post-GFC.

H1c: Firms that increased innovativeness during the GFC increased their commodity product focus post-GFC.

\section{Results and discussion}

A surprising proportion of our responding firms claim to have increased innovativeness as a mechanism to combat the chaos of the GFC. Over half of our respondents increased their level of innovativeness in response to the GFC. While increasing innovativeness does not necessarily require a significant increase in expenditure, this finding is in contrast to the finding that approximately $6 \%$ of European firms increased innovation expenditure in response to the crisis (Filippetti and Archibugi 2011).

Although the literature is filled with examples of studies showing a positive relationship between innovativeness and firm performance (Tsai and Yang 2013; Rubera and 
Kirca 2012), there is no significant performance difference between responding firms based on levels of innovativeness (Table 1). While not statistically different, findings are in the direction expected, and a larger sample may have allowed detection of a difference. The lack of difference suggests that increasing innovativeness may be of questionable value. On the other hand, innovation requires long-term capability development by the firm. Emergency innovation efforts triggered by the GFC might have been less effective than usual if not supported by necessary capabilities. What we find through further analysis shows that many companies initially increased innovativeness in response to the GFC, but subsequently slid backwards in innovativeness efforts. Accordingly, our results may not be indicative of the potential outcome from sustained innovativeness efforts since being intrinsically instead of occasionally innovative is shown to improve performance (Forsman and Temel 2011). Still, there is some evidence that despite slipping backwards, overall innovativeness remained higher than before the GFC (Table 2).

In the case of small firms, non-innovators perform better on some metrics (e.g., return on investment) than innovators (Forsman and Temel 2011). Although we do not have data regarding ownership of responding firms, the high proportion of small firms and the general nature of the forest sector suggest that most responses came from private companies. Managers with more ownership of a firm tend to reduce innovation expenditure at a greater rate than those with less during a crisis (Latham and Braun 2009). Our results, along with existing literature, do not lead to a definitive answer with respect to the innovativeness $\rightarrow$ performance relationship, but we expect capitalizing on increased innovativeness requires appropriate capabilities, which may take some time to develop. Therefore, companies should consider innovation investments/activities across the business cycle as a more consistent approach may be more productive.

Based on historical evidence, H1a suggested that firms increasing innovativeness in response to the GFC most likely returned to traditional ways as markets recovered. Table 2 outlines comparisons between time periods with respect to product and process and business systems innovativeness. The pattern is consistent between the innovativeness types, first, an increase in response to the GFC, followed by a return toward less innovative ways. The slide back toward old norms was not as evident from the perspective of process and business systems innovativeness. However, given the sample size, the 0.07 level of significance is fairly indicative of a meaningful reduction in innovativeness in this area as well.

To gain a slightly different view of this potential advance/retreat pattern among responding firms, H1b proposed that as markets improved, firms would cease to invest in innovative efforts and would instead retreat to former comfort zones. Table 3 outlines the results of comparing 2012 values to 2015 values in each of the nine innovation efforts. Half of the items trended in the expected direction with a reduction in innovation efforts, one item stayed the same, and two were in the opposite direction of

Table 1 Change in financial performance (2012-2015) among firms with equal or decreased innovativeness versus firms with increased innovativeness (2008-2012)

\begin{tabular}{lllllrr}
\hline & $N$ & Mean & SD & Mean diff. & Std. error diff. & Sig. \\
\hline Equal or lower innovativeness & 39 & 3.44 & 0.97 & -0.26 & .021 & 0.22 \\
Increased innovativeness & 42 & 3.70 & 0.91 & & & \\
\hline
\end{tabular}


Table 2 Change in innovativeness pre-GFC to 2012 to $2015(n=46)$

\begin{tabular}{lllccc}
\hline & Mean & SD & Mean diff. & Std. error diff. & Sig. \\
\hline Product innovativeness, pre-GFC (2008) & 2.78 & 0.81 & 0.76 & 0.83 & $.000^{* *}$ \\
Product innovativeness, 2012 & 3.54 & 0.86 & -0.37 & 1.14 & $.033^{*}$ \\
Product innovativeness, 2015 & 3.17 & 1.14 & & & \\
Process and bus. systems innovativeness, pre-GFC (2008) & 2.92 & 0.90 & 0.64 & 0.80 & $.000^{* *}$ \\
Process and bus. systems innovativeness, 2012 & 3.56 & 0.80 & -0.25 & 0.93 & .071 \\
Process and bus. systems innovativeness, 2015 & 3.31 & 0.86 & & & \\
\hline
\end{tabular}

Paired samples $t$ test, ${ }^{*} P<0.05,{ }^{* *} P<0.01$

that expected. There were only two items that were significantly different $(P<.05)$ between the time periods, less flexible in production and not being as aggressive with business tactics/practices. This likely reflects the reality of returning to traditional markets and provides some evidence to support the retreat thesis. It appears that as domestic markets recovered, firms found themselves with increased slack resources that they tended to invest in sales and marketing activities, but the positive increases over time are not statistically significant $(P>0.05)$.

A final way of looking at the potential shift in focus during the market recovery is the product focus of firms. Accordingly, H1c proposed that as markets recovered, firms shifted more toward commodity products. Table 4 shows that there is no evidence $(P>0.05)$ of this shift and that the proportion of commodity production within firms did not change between 2012 and 2015.

Table 3 Change in innovative efforts between 2012 and $2015(n=46)$

\begin{tabular}{lllccc}
\hline & Mean & SD & Mean diff. & Std. error diff. & Sig. \\
\hline Developing new foreign markets, 2012 & 3.33 & 0.81 & 0.30 & 1.25 & 0.12 \\
Developing new foreign markets, 2015 & 3.02 & 0.91 & & & \\
Developing new domestic markets, 2012 & 4.22 & 0.90 & 0.00 & 1.04 & 1.00 \\
Developing new domestic markets, 2015 & 4.22 & 0.80 & & & \\
Investing in promotion/advertising, 2012 & 3.16 & 0.85 & -0.27 & 1.10 & 0.11 \\
Investing in promotion/advertising, 2015 & 3.42 & 0.84 & & & \\
Investing in sales, 2012 & 3.43 & 0.73 & -0.18 & 1.08 & 0.27 \\
Investing in sales, 2015 & 3.61 & 0.81 & & & \\
Developing new products, 2012 & 3.91 & 0.85 & 0.09 & 0.97 & 0.54 \\
Developing new products, 2015 & 3.82 & 0.86 & & & \\
Being more flexible with production, 2012 & 4.31 & 0.67 & 0.31 & 0.93 & \\
Being more flexible with production, 2015 & 4.00 & 0.60 & & & \\
Aggressiveness of business tactics/practices, 2012 & 4.11 & 0.71 & 0.38 & 0.89 & 0.01 \\
Aggressiveness of business tactics/practices, 2015 & 3.73 & 0.75 & & & \\
Acquisition of competing companies, 2012 & 2.97 & 0.74 & -0.05 & 1.03 & 0.76 \\
Acquisition of competing companies, 2015 & 3.03 & 0.81 & & & \\
Investing in customer relationships, 2012 & 4.16 & 0.71 & 0.06 & 0.90 & 0.25 \\
Investing in customer relationships, 2015 & 4.00 & 0.71 & & & \\
\hline Pared samplest & & & & & \\
\hline
\end{tabular}

Paired samples $t$ test, ${ }^{*} P<0.05,{ }^{* *} P<0.01$ 
Table 4 Change in commodity focus, 2012-2015 $(n=46)$

\begin{tabular}{lllccc}
\hline & Mean & SD & Mean diff. & Std. error diff. & Sig. \\
\hline Commodity focus, 2012 & 47.67 & 33.80 & -3.86 & 26.71 & 0.349 \\
Commodity focus, 2015 & 43.81 & 35.07 & & & \\
\hline
\end{tabular}

\section{Conclusions}

Overall, the evidence provides support for our original argument that firms returned toward old ways of operating once the economy began recovering and the impetus for innovation dissipated. Firms that increased innovativeness as a reaction to the GFC tend to subsequently decrease innovativeness as markets recovered. With respect to innovative activities, the decreased focus on production flexibility and aggressive business tactics is consistent with $\mathrm{H} 1 \mathrm{~b}$. For commodity producers that typically focus on a low-cost strategy (Hansen et al. 2006), shifting to less-flexible and high-volume production is consistent with theory. Flexibility during the recession meant being open to producing alternative products that in "normal" times would be seen as not worth the effort or too disruptive to high-volume production processes. In contrast to this, we did not find the expected shift to a higher proportion of commodity production. Being less cut-throat with business practices is also consistent with theory. On the other hand, firms increased focus on promotion and sales activities $(P<0.05)$, which is opposite to what was proposed in $\mathrm{H} 1 \mathrm{~b}$, though it is consistent with returning to traditional markets, and for example, re-staffing in the sales department.

With our small sample size, we were unable to capture a sufficient number of firms that increased and sustained innovativeness across the timeframe of this study to identify if a sustained increase in innovativeness has a meaningful impact on financial performance. This would be a valuable area for future research. In addition, capturing situations where firms proactively increase innovativeness in one area while at the same time strategically reduce elsewhere would be a valuable addition to the present study. Archibugi et al. (2013a) and Laperche et al. (2011) suggest this to be a probable strategy and future work should be designed to capture this phenomenon. In addition, the findings from Madrid-Guijarro et al. (2013) show the relative importance of type of innovation (product, process, business systems) changes over the business cycle, reinforcing the need to separate these issues in future research.

\section{Methods}

The following sub-sections explain the methods employed in the study. First is an explanation of the sample frame and sampling methodology. Next is a discussion of the various steps involving measurement, questionnaire pretesting, and data collection. Finally, analyses conducted to address study objectives are explained.

\section{Sampling and sample frame}

In an original study conducted in 2013, data was sought from manufacturers with 50 or more employees from the US wood products (SIC 24) sector. A database of 976 firms was purchased from the North American Industrial Classification Association. In that study, 142 companies responded. The current study sought updated information from each of these 142 companies. 
Measures

Innovativeness (2008, 2012, and 2015)

Innovativeness was measured using an adaptation of the scale developed by Knowles et al. 2008 and used by Nybakk (2012). The scale accounts for creation and adoption of products, manufacturing processes, and business systems. Each dimension is represented by four items. A 5-point interval scale was used with respondents providing their evaluation of the innovativeness of their company. Only the extreme points of the scale were labeled, where $1=$ not at all innovative and $5=$ very innovative.

Innovation efforts (2015)

A set of nine activities was used to gauge the investment of companies in what is considered innovative efforts: developing new foreign markets, developing new domestic markets, investing in promotion/advertising, investing in sales, developing new products, being more flexible with production, aggressiveness of business tactics/practices, acquisition of competing companies, and investing in customer relationships. A 5-point interval scale was used, where $1=$ decreased, $3=$ stayed the same, and $5=$ increased.

Points 2 and 4 were not labeled.

\section{Financial performance (2015)}

Financial performance was assessed by adapting subjective measures that are recommended and used in a number of previous studies (e.g., Nybakk and Jenssen 2012; Morgan and Strong 2003; Beal 2000; Dess and Robinson 1984). The following four items representing different aspects of financial performance were used: return on sales, sales growth rate, after tax return on assets, and gross profit margin. Respondents were asked to compare their performance between 2012 and 2015 on a 5-point scale, where 1 = much lower and 5 = much higher.

\section{Product focus (2012 and 2015)}

The product focus of each firm was assessed via the proportion of overall production in each of three categories: commodity, specialty, and custom-made.

\section{Data collection}

In a 2013 survey (Hansen 2014), following the general principles of the Tailored Design Method (Dillman 2007), 941 questionnaires were sent and 142 valid responses were received for an adjusted response rate of $15.1 \%$. The current study sought responses from each of the 142 respondents to the 2013 study. Accordingly, questionnaires were sent to each of the previous respondents and a total of 89 responses were received (six companies were no longer in business) for a response rate of $65.4 \%$ (Table 5). Respondents

Table 5 Population and sample description for 2013 and 2016 surveys

\begin{tabular}{llll}
\hline & Questionnaires mailed & Valid responses & Adjusted response rate \\
\hline 2013 survey & 941 & 142 & $15.1 \%$ \\
2016 survey & 142 & 89 & $65.4 \%$ \\
\hline
\end{tabular}

Data from the two surveys represent respondent operations in 2008, 2012, and 2016 
Table 6 Pearson's correlation matrix for key study variables

\begin{tabular}{|c|c|c|c|c|c|c|c|c|c|c|c|}
\hline & 2 & 3 & 4 & 5 & 6 & 7 & 8 & 9 & 10 & 11 & $12^{+}$ \\
\hline $\begin{array}{l}\text { 1. Overall innovativeness } \\
2008\end{array}$ & $.530^{* *}$ & $.504^{* *}$ & $.757^{* *}$ & $.342^{* *}$ & $.410^{* *}$ & $.936^{* *}$ & $.518^{* *}$ & $.454^{* *}$ & .181 & .094 & .102 \\
\hline $\begin{array}{l}\text { 2. Overall innovativeness } \\
2012\end{array}$ & & $.426^{* *}$ & $.399^{* *}$ & $.722^{* *}$ & $.271^{*}$ & $.500^{* *}$ & $.926^{* *}$ & $.435^{* *}$ & $.353^{* *}$ & .022 & .095 \\
\hline $\begin{array}{l}\text { 3. Overall innovativeness } \\
2015\end{array}$ & & & $.324^{* *}$ & $.327^{* *}$ & $.791^{* *}$ & $.506^{* *}$ & $.394^{* *}$ & $.914^{* *}$ & $.435^{* *}$ & .007 & .066 \\
\hline $\begin{array}{l}\text { 4. Product innovativeness } \\
2008\end{array}$ & & & & $.594^{* *}$ & $.434^{* *}$ & $.481^{* *}$ & .208 & .180 & -.116 & -.075 & .005 \\
\hline $\begin{array}{l}\text { 5. Product innovativeness } \\
2012\end{array}$ & & & & & $.422^{* *}$ & .146 & $.411^{* *}$ & .192 & .043 & -.181 & -.032 \\
\hline $\begin{array}{l}\text { 6. Product innovativeness } \\
2015\end{array}$ & & & & & & $.319^{* *}$ & .132 & $.476^{* *}$ & .162 & .014 & .070 \\
\hline $\begin{array}{l}\text { 7. Process and business } \\
\text { systems innovativeness } 2008\end{array}$ & & & & & & & $.586^{* *}$ & $.518^{* *}$ & $.312^{* *}$ & .163 & .133 \\
\hline $\begin{array}{l}\text { 8. Process and business } \\
\text { systems innovativeness } 2012\end{array}$ & & & & & & & & $.480^{* *}$ & $.442^{* *}$ & .123 & .143 \\
\hline $\begin{array}{l}\text { 9. Process and business } \\
\text { systems innovativeness } 2015\end{array}$ & & & & & & & & & $.509^{* *}$ & -.002 & .048 \\
\hline $\begin{array}{l}\text { 10. Change in } \\
\text { performance }\end{array}$ & & & & & & & & & & .042 & .046 \\
\hline $\begin{array}{l}\text { 11. Commodity focus } \\
2012\end{array}$ & & & & & & & & & & & $.698^{* *}$ \\
\hline
\end{tabular}

*Significant at 5\% level

**Significant at $1 \%$ level

${ }^{+} 12=$ commodity focus 2015

to the 2013 survey provided data regarding their operations in 2008 and 2012 while respondents to the 2016 survey provided data regarding their operations in 2015. Non-response bias was tested comparing the 89 respondents to the 47 non-respondents on all main study variables, using data from 2013, and no significant differences were found. This suggests non-response bias should not be a significant concern in this data set.

\section{Data analysis}

Confirmatory factor analyses were conducted based on data from the first survey, conducted in $2013(n=142)$ using the structural equation modeling tool EQS (Byrne, 2006). For the second round dataset, only reliability analyses were conducted, due the low number of observations $(n=89)$. However, the two surveys were based on the same measurements conducted among the same respondents, and the results suggest that both convergent and discriminant validities were achieved $(\mathrm{CFI}=0.903$, IFI $=0.905$, and RMSEA $=0.092)$. Fornell and Larcker's (1981) test indicated discriminant validity in the survey data. The average variance extracted (AVE) varied from 0.43 to 0.65 . In the second round, analyzing the 89 respondents, all analyses were performed using SPSS 21 software. The data were first thoroughly error checked. Generally, composite variables were used in analysis. For example, product innovativeness was the mean of the four items measuring that construct. Based on analysis in Hansen (2014), process and business systems innovativeness were merged to form one dimension. 
Table 7 Measurement items, confirmatory factor analyses, and reliability analysis

\begin{tabular}{|c|c|c|c|}
\hline & \multicolumn{3}{|c|}{ Corrected item-total correlation } \\
\hline & Pre-GFC & 2012 & 2015 \\
\hline \multicolumn{4}{|l|}{ Product innovativeness (CA 2008 $=.83$, CA 2012 $=.80$, CA 2015 $=.81$, AVE $\left.^{*}=0.43\right)$} \\
\hline Our company actively develops new products in-house & .648 & .592 & .661 \\
\hline Our company actively seeks new products from outside this organization & .554 & .546 & .412 \\
\hline Our company sees creating new products as critical to our success & .789 & .742 & .790 \\
\hline $\begin{array}{l}\text { When it comes to creating new products, our company is far better } \\
\text { than the competition }\end{array}$ & .674 & .602 & 697 \\
\hline \multicolumn{4}{|c|}{ Process and business systems innovativeness (CA 2008 $=.90$, CA 2012 $=.91$, CA $2015=.88$, AVE $\left.^{*}=0.46\right)$} \\
\hline $\begin{array}{l}\text { Our company tends to be an early adopter of new } \\
\text { manufacturing processes }\end{array}$ & .726 & .726 & .731 \\
\hline $\begin{array}{l}\text { Our company sees creating new manufacturing processes } \\
\text { as critical to our success }\end{array}$ & .768 & .768 & .578 \\
\hline $\begin{array}{l}\text { Our company actively seeks new manufacturing processes } \\
\text { from outside } \\
\text { this organization }\end{array}$ & .670 & .670 & .550 \\
\hline $\begin{array}{l}\text { When it comes to creating new processes, our company is } \\
\text { far better than the competition }\end{array}$ & .665 & .665 & .682 \\
\hline Our company tends to be an early adopter of new business systems & .746 & .746 & .739 \\
\hline Our company actively develops in-house business systems solutions & .597 & .597 & .582 \\
\hline Our company sees creating new business systems as critical to our success & .708 & .708 & .627 \\
\hline $\begin{array}{l}\text { When it comes to creating new business systems, our company } \\
\text { is far better than the competition }\end{array}$ & .744 & .744 & .705 \\
\hline \multicolumn{4}{|l|}{ Change in performance 2012-2015 (CA $=.91$, AVE $\left.^{*}=0.65\right)$} \\
\hline Improving yield or reduced material consumption & & & .880 \\
\hline Reduce production costs & & & .573 \\
\hline Improving production flexibility & & & .897 \\
\hline Improving existing product quality & & & .876 \\
\hline \multicolumn{4}{|l|}{ Fit values** } \\
\hline \multicolumn{4}{|l|}{ Comparative fit index $(\mathrm{CFI})=0.903$} \\
\hline \multicolumn{4}{|l|}{ Incremental fit index $(I F \mid)=0.905$} \\
\hline Comparative fit index $(\mathrm{CFI})=0.092$ & & & \\
\hline
\end{tabular}

CA Cronbach's alpha, AVE average variance extracted

*AVE based on the original 2013 study measuring innovativeness and performance between 2008 and 2012 ( $n=141$ )

**Fit values are based on the original 2013 study measuring innovativeness and performance between 2008 and

$2012(n=141)$

Our analysis is based on the 89 respondents from the most recent survey, comparing the respondent company situation in 2008, 2012, and 2015. Table 6 provides a correlation matrix for key study variables, while Table 6 outlines the innovativeness items and Cronbach's Alpha for each of the dimensions for data representing pre-GFC (2008), 2012 and 2015. All alpha levels are acceptable with the lowest value being for 2012 product innovativeness $(0.80)$ (Table 7$)$.

\section{Acknowledgements}

The authors would like to thank Beniamino Callegari and Bisrat Agegnehu for their insightful comments on an early version of this manuscript. 
Availability of data and materials

Data can be obtained from the corresponding author.

\section{Authors' contributions}

EH conceived the study, collected the data, and led the creation of text. EN assisted in the study design, conducted all the analyses, and assisted with the text creation. Both authors read and approved the final manuscript.

\section{Competing interests}

The authors declare they have no competing interests.

\section{Publisher's Note}

Springer Nature remains neutral with regard to jurisdictional claims in published maps and institutional affiliations.

\section{Author details}

'Department of Wood Science and Engineering, College of Forestry, Oregon State University, 119 Richardson Hall, Corvallis, OR 97331, USA. ${ }^{2}$ Kristiania University College, PB 1190 Sentrum, 0107 Oslo, Norway. ${ }^{3}$ Department of Strategy, BI Norwegian Business School, 0442 Oslo, Norway.

Received: 6 March 2018 Accepted: 13 July 2018

Published online: 14 August 2018

\section{References}

Amore, MD. (2015). Companies learning to innovate in recessions. Research Policy, 44(8), 1574-1583.

Archibugi, D. (2017). The social imagination needed for an innovation-led recovery. Research Policy, 46(3), 554-556.

Archibugi, D, Filippetti, A, Frenz, M. (2013a). Economic crisis and innovation: Is destruction prevailing over accumulation? Research Policy, 42(2), 303-314.

Archibugi, D, Filippetti, A, Frenz, M. (2013b). The impact of the economic crisis on innovation: evidence from Europe. Technological Forecasting and Social Change, 80(7), 1247-1260.

Bancel, F, \& Mittoo, UR. (2011). Financial flexibility and the impact of the global financial crisis: evidence from France. International Journal of Managerial Finance, 7(2), 179-216.

Beal, RM. (2000). Competing effectively: environmental scanning, competitive strategy, and organizational performance in small manufacturing firms. Journal of Small Business Management, 38, 27-47.

Brancati, E, Brancati, R, Maresca, A. (2017). Global value chains, innovation and performance: firm-level evidence from the Great Recession. Journal of Economic Geography, 17(5), 1039-1073.

Brzozowski, J, \& Cucculelli, M. (2016). Proactive and reactive attitude to crisis: evidence from European firms. Entrepreneurial Business and Economics Review, 4(1), 181-191.

Byrne, BM (2006). Structural equation modeling with EQS: basic concepts, applications, and programming, (2nd ed., ). Mahwah, NJ: Erlbaum.

Cefis, E, \& Marsili, O. (2005). A matter of life and death: innovation and firm survival. Industrial and Corporate Change, 14(6), 1167-1192.

Dess, GG, \& Robinson, RB. (1984). Measuring organizational performance in the absence of objective measures: the case of the privately-held firm and conglomerate business unit. Strategic Management Journal, 5, 265-273.

Dillman, D (2007). Mail and internet surveys: The Tailored Design Method 2nd edition. Hoboken, New Jersey.: John Wiley \& Sons, Inc.

Ferreira, A, \& Teixeira, AL. (2016). Intra- and extra-organizational foundations of innovation processes: the information and communication technology sector under the crisis in Portugal. International Journal of Innovation Management, 20(6), 1650056. https://doi.org/10.1142/S1363919616500560.

Filippetti, A, \& Archibugi, D. (2011). Innovation in times of crisis: national systems of innovation, structure, and demand Research Policy, 40(2), 179-192.

Florida, R (2010). The great reset. Canada: Random House.

Fornell, C, \& Larcker, DF. (1981). Evaluating structural equation models with unobservable variables and measurement error. Journal of Marketing Research, 18(1), 39-50.

Forsman, H, \& Temel, S. (2011). Innovation and business performance in small enterprises: an enterprise-level analysis. International Journal of Innovation Management, 15(03), 641-665.

Garcia, R, \& Calantone, R. (2002). A critical look at technological innovation typology and innovativeness terminology: a literature review. Journal of Product Innovation Management, 19(2), 110-132.

Gebert, D, Boerner, S, Lanwehr, R. (2003). The risks of autonomy: empirical evidence for the necessity of a balance management in promoting organizational innovativeness. Creativity and Inn Mgmt, 12, 41-49.

Han, X, \& Hansen, E. (2016). Marketing sophistication in private sawmilling companies in the United States. Canadian Journal of Forest Research, 46(2), 181-189.

Hansen, E. (2014). Innovativeness in the face of decline: performance implications. International Journal of Innovation Management, 18(05), 1450039.

Hansen, E, Dibrell, C, Down, J. (2006). Market orientation, strategy, and performance in the primary forest industry. Forest Science, 52(3), 209-220.

Hausman, A, \& Johnston, WJ. (2014). The role of innovation in driving the economy: lessons from the global financial crisis. Journal of Business Research, 67(1), 2720-2726.

Holl, A, \& Rama, R. (2016). Persistence of innovative activities in times of crisis: the case of the Basque Country. European Planning Studies, 24(10), 1863-1883.

Hovgaard, A, \& Hansen, E. (2004). Innovativeness in the forest products industry. Forest Products Journal, 54(1), 26-33. 
Ince, PJ, \& Nepal, P (2012). Effects on U.S. timber outlook of recent economic recession, collapse in housing construction, and wood energy trends. General Technical Report FPL-GTR-219. Madison: USDA Forest Service Forest Products Lab.

Knowles, C, Hansen, E, Shook, S. (2008). Assessing innovativeness in the North American softwood sawmilling industry using three methods. Canadian Journal of Forest Research, 38, 363-375.

Laperche, B, Lefebvre, G, Langlet, D. (2011). Innovation strategies of industrial groups in the global crisis: rationalization and new paths. Technological Forecasting and Social Change, 78(8), 1319-1331.

Latham, S. (2009). Contrasting strategic response to economic recession in start-up versus established software firms. Journal of Small Business Management, 47(2), 180-201.

Latham, SF, \& Braun, M. (2009). Managerial risk, innovation, and organizational decline. Journal of Management, 35(2), 258-281.

Llach, J, Marquès, P, Bikfalvi, A, Simon, A, Kraus, S. (2012). The innovativeness of family firms through the economic cycle. Journal of Family Business Management, 2(2), 96-109.

Madrid-Guijarro, A, Garcia-Perez-de-Lema, D, Van Auken, H. (2013). An investigation of Spanish SME innovation during different economic conditions. Journal of Small Business Management, 51(3), 578-601.

McKinley, W, Latham, S, Braun, M. (2014). Organizational decline and innovation: turnarounds and downward spirals. Academy of Management Review, 39(1), 88-110.

Morgan, RE, \& Strong, CA. (2003). Business performance and dimensions of strategic orientation. Journal of Business Research, 56, 163-176.

Nybakk, E. (2012). Learning orientation, innovativeness and financial performance in traditional manufacturing firms: a higher-order structural equation model. International Journal of Innovation Management, 16, 28.

Nybakk, E, \& Jenssen, J. (2012). Innovation strategy, working climate, and financial performance in traditional manufacturing firms: an empirical analysis. International Journal of Innovation Management, 16, 26.

Panwar, R, Vlosky, R, Hansen, E. (2012). Gaining competitive advantage in the new normal. Forest Products Journal, 62, $420-428$.

Paunov, C. (2012). The global crisis and firms' investments in innovation. Research Policy, 41, 24-35.

Petrakis, PE, Kostis, PC, Valsamis, DG. (2015). Innovation and competitiveness: culture as a long-term strategic instrument during the European Great Recession. Journal of Business Research, 68(7), 1436-1438.

Price, DP, Stoica, M, Boncella, RJ. (2013). The relationship between innovation, knowledge, and performance in family and non-family firms: an analysis of SMEs. Journal of innovation and Entrepreneurship, 2(1), 14.

Pro Inno Europe (2008). European innovation scoreboard 2007. Comparative analysis of innovation performance, (p. 52). Maastricht: Pro Inno Europe - Inno Metrics.

Rich, SU. (1981). Product policy in the overseas export market. Forest Products Journal, 31(6), 16-17.

Rogers, EM (2003). Diffusion of innovations, (5th ed., ). New York, NY: Free Press.

Rollins, M, Nickell, D, Ennis, J. (2014). The impact of economic downturns on marketing. Journal of Business Research, 67(1), 2727-2731

Rubera, G, \& Kirca, AH. (2012). Firm innovativeness and its performance outcomes: a meta-analytic review and theoretical integration. Journal of Marketing, 76(3), 130-147.

Sarkar, S, \& Osiyevskyy, O. (2018). Organizational change and rigidity during crisis: a review of the paradox. European Management Journal, 36, 47-58.

Sasatani, D, \& Eastin, IL. (2016). Significant factors impacting export decisions of small-and medium-sized softwood sawmill firms in North America. Canadian Journal of Forest Research, 46(1), 67-76.

Sempre-Ripoll, F, \& Hervás-Oliver, JL (2014). In times of economic crisis: innovation with, or without, R\&D activities? An analysis of Spanish companies. In K Rüdiger, M Peris-Ortiz, A Blanco-González (Eds.), Entrepreneurship, innovation and economic crisis. Springer International Publishing Switzerland 181 pp.

Srinivasan, R, Rangaswamy, A, Lilien, GL. (2005). Turning adversity into advantage: Does proactive marketing during a recession pay off? International Journal of Research in Marketing, 22(2), 109-125.

Staw, BM, Sandelands, LE, Dutton, JE. (1981). Threat-rigidity effects in organizational behavior: a multilevel analysis. Administrative Science Quarterly, 26(4), 501-524.

Sun, X, Lee, SH, Phan, PH. (2018). Family firm R\&D investments in the 2007-2009 great recession. Journal of Family Business Strategy (In Press).

Tansey, P, Spillane, JP, Meng, X. (2014). Linking response strategies adopted by construction firms during the 2007 economic recession to Porter's generic strategies. Construction Management and Economics, 32(7-8), 705-724.

Tsai, KH, \& Yang, SY. (2013). Firm innovativeness and business performance: the joint moderating effects of market turbulence and competition. Industrial Marketing Management, 42(8), 1279-1294.

USDA. (2018). United States Department of Agriculture, Forest Agricultural Service, Global Agricultural Trade System Online. https://apps.fas.usda.gov/Gats/default.aspx. Last Accessed on July 12, 2018.

Zouaghi, F, Sánchez, M, Martínez, MG. (2018). Did the global financial crisis impact firms' innovation performance? The role of internal and external knowledge capabilities in high and low tech industries. Technological Forecasting and Social Change, 132, 92-104. 